\title{
Density and Distribution of False Smut Balls on Infected Rice Panicles
}

\author{
B Nessa ${ }^{1,2}$, M U Salam³, A H M M Haque ${ }^{1}$, J K Biswas², Q S A Jahan², M A I Khan², \\ M R Bhuiyan², A Ara', M R Munir², J Galloway ${ }^{3}$, MS Kabir² and M A Ali²
}

\begin{abstract}
Rice false smut (RFSm), considered as a minor importance, has become a serious disease in many rice growing areas of Bangladesh and other parts of the world. Many aspects of its epidemiology still remained unclear, notable the life cycle of RFSm pathogen, its infection site and the smut ball formation on infected panicles. Present research was undertaken to investigate the density and distribution of false smut balls on infected rice panicles aiding to understand on how severe the disease can be in a rice-ecosystem, on which position the smut balls form on infected panicles and likely yield reduction from such disease severity. This study included field observation of natural RFSm infection during 2014, 2015 and 2016, and simulated infection during 2015 in T. Aman rice in the experimental farm of the Bangladesh Rice Research Institute (BRRI), Gazipur, Bangladesh. While the number of smut balls reached as many as 136 (recorded in one panicle in 2015), the study shows there was 81,54 and $30 \%$ probability that maximum of nine, three and only one smut ball would form, respectively. With the scenarios of density of smut ball formation in the study area, the yield loss was estimated as $0.15 \%$ for each $1 \%$ incidence level. The level of smut ball density varied between years; this severity was most likely influenced by low daily minimum temperature. In the natural observation $34.4,53.9$ and $11.7 \%$ of the smut balls were located at the base, mid and apex part of the infected panicles, respectively. When compared the balls of these three positions in relation to potential grain number, the proportion accounted for the base and mid remained almost similar, whereas the proportion in the apex was much lower. It is concluded that false smut balls predominantly form on the lower half of the infected rice panicles.
\end{abstract}

Key words: False smut infection route; infection process simulation, filled grains, Ustilaginoidea virens

\section{INTRODUCTION}

Rice false smut (RFSm) is recognized worldwide as an emerging fungal disease (anamorph: Ustilaginoidea virens (Cooke) Takah.; teleomorph Villosiclava virens (Nakata) E. Tanaka \& C. Tanaka) of rice (Oryza sativa L.) (Atia, 2004; Brooks et al., 2009; Ashizawa et al., 2010; Li et al., 2013; Singh et al., 2014). The importance of the disease in Bangladesh has been highlighted in recent literatures (Nessa et al., 2015a, b, and c). The disease is predominant during T. Aman (late monsoonal rice) season in the country, which is hindering adoption of promising rice varieties, such as BRRI dhan 49 (Kabir et al., 2015).
RFSm is an inflorescence disease. The symptom of the disease only appears after rice crops flower. It affects separate panicles (floral organs) where the fungus infects individual spikelets and replaces the grain with a large, velvety orange to green balls, known as smut balls (Ou, 1972).

Yield loss from RFSm has been reported in the range of below 1 (Atia, 2004) to over 75\% (Upadhyay and Singh, 2013). The quantity of false smut balls on infected rice panicles largely explains variation of yield loss from the disease (Nessa et al., 2015a). However, little information is available on the density of false smut balls on naturally infected rice panicles, especially under Bangladesh conditions.

${ }^{1}$ Department of Plant Pathology and Seed Science, Sylhet Agricultural University, Sylhet 3100, Bangladesh; ${ }^{2}$ Bangladesh Rice Research Institute (BRRI), Gazipur 1701, Bangladesh; and ${ }^{3}$ Department of Agriculture and Food Western Australia (DAFWA), South Perth, WA6151, Australia. *Corresponding author's E-mail: runu.brri@yahoo.com 
Fan et al. (2015) notes, 'As false smut ball is the only visible symptom of the disease, deciphering the host-pathogen interaction leading to smut ball formation is of particular importance to fully understand and effectively control the disease'. As it is a floral disease and doesn't show any symptom before flowering, it seems that the fungus infects the spikelets either in booting stage or just after flowering. However, whether the entry route of the pathogen through the junction of flag leaf and ligule, or below the base of the panicle, is still unknown. The pattern of ball formation on panicles may help open some mystery in this regard.

With the above background, the present research was undertaken to investigate the density and distribution of false smut balls on different parts of infected panicles and to explore the possible infection route of the fungus into the plants under natural condition.

\section{MATERIALS AND METHODS}

The number of false smut balls on naturally infected rice panicles was studied on 2,498 samples. The samples (panicles containing false smut balls) were collected from the research farm of the Bangladesh Rice Research Institute (BRRI), Gazipur, Bangladesh (23⒌ $9^{\prime}$ N, 90 $24^{\prime}$

E) during T. Aman season. This farm has built up as an intensive rice-ecosystem over the last 40 years while growing rice in as many as three seasons annually in about 88 fields spread over 35 hectares area. It is situated at about $35 \mathrm{~m}$ above the mean sea level and has a subtropical climate strongly influenced by the south-western monsoon (Nessa et al., 2015a). The samples were collected randomly in 2014 (1337 samples), 2015 (516 samples) and 2016 (645 samples) during late ripening stage of the crop (late October to late November). In this study BRRI dhan 49 was used as a test variety.

To investigate the distribution of false smut balls on infected rice panicles, 336 panicles across the smut ball density were collected from the same rice-ecosystem during $2015 \mathrm{~T}$. Aman rice season.
The simulated infection was conducted by dripping coloured spray drops through the junction of flag leaf and ligule in the late boot stage of rice on 50 panicles during $2015 \mathrm{~T}$. Aman season (Photo 1).

Simulation experiment mimicking false smut fungal spores was dripping as liquid dye water droplets in order to colour spikelets (grains) by contact of the droplets as they pass through the passage.

The density of false smut balls on infected rice panicles was measured by count. The distribution of false smut balls on infected rice panicles was measured by count in three positions of the sampled panicles - base, mid and apex (Photo 2). These three positions were ascertained by measuring the whole length of the panicles (from base to the tip) and dividing
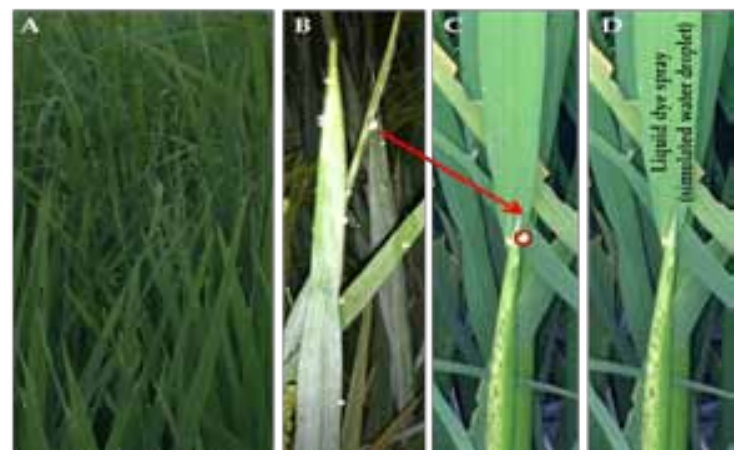

Photo 1. Water drops (A, B) dripping during late afternoon to following morning through the junction of flag leaf and ligule $(\mathrm{C})$ in the late boot stage of rice crop grown under natural environment in the research farm of BRRI, Gazipur, Bangladesh. Rice false smut fungal spores enter through the dripping water drops (D).

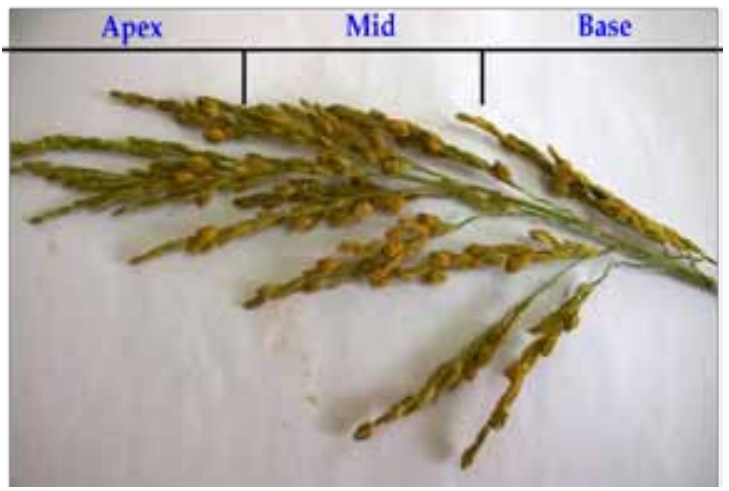

Photo 2. Three divisions (base, mid and apex) of an infected rice panicle made to measure the distribution of false smut balls. 
by three. In the simulated experiment, coloured grains (because of contact of dripping dye) were considered as smut balls.

Density and yearly variation of false smut balls on infected rice panicles were expressed in probability and cumulative probability function, respectively. In order to explain the yearly variability in the density of false smut balls on infected rice panicles, daily weather data, measured by the BRRI Plant Physiology Division were used.

The yield loss was estimated according to Nessa et al. (2015a) as below:

Yield loss $(\%)=(\mathrm{DI} / 100) \times[0+100 \times(1-\mathrm{e} 0.03 \times \mathrm{bp})]$

Where, DI is the disease incidence and bp is the number of smut balls per infected panicle.

Regression analysis was done on concentration of false smut balls (summarized as percentage of 5-balls group) in relation to number of smut ball for three positions (base, mid and apex) of infected panicles. The number of filled and unfilled grains on 50 healthy panicles, collected from the same rice-ecosystem during 2015, was summarized as mean and 95\% confidence interval (Willmott et al., 1985). The data on false smut balls in three positions of naturally and simulated infected panicles were also summarized as mean and $95 \%$ confidence interval. The level of variability in false smut balls on naturally and simulated infected panicles in three positions across nine panicle lengths (16 to $24 \mathrm{~cm}$, interval 1) was estimated using the concordance correlation coefficient (CCC), $\rho c$ (Lin, 1989).

\section{RESULTS}

\section{Density and yearly variation of false smut balls on infected rice panicles}

As many as 67, 136 and 45 false smut balls were identified on infected panicles in 2014, 2015 and 2016, respectively. The probability of occurring 1, 2, 3, 4 and 5 false smut balls per infected panicle was $\sim 30 \%, \sim 14 \%, \sim 10 \%, \sim 7 \%$ and $\sim 6 \%$, respectively (Fig. 1). In other words, there was two-third chance that the maximum of five smut balls would be found on infected rice panicles.

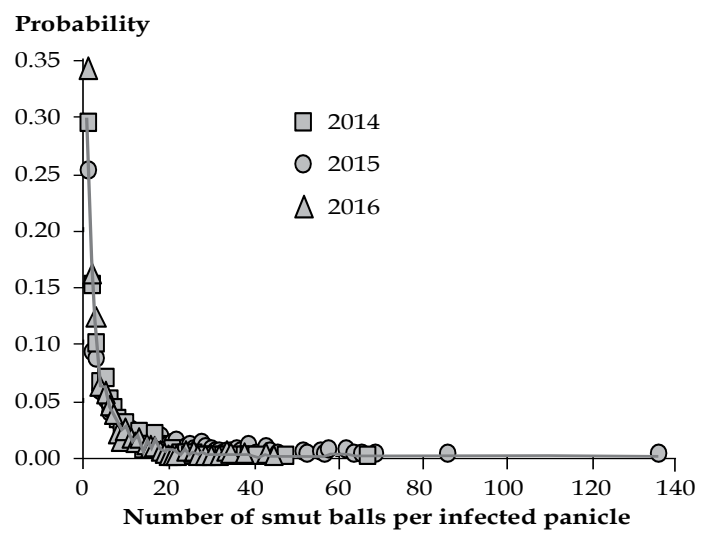

Fig. 1. Probability of occurring number of false smut balls on infected rice panicles in three T. Aman seasons 2014, 2015 and 2016.

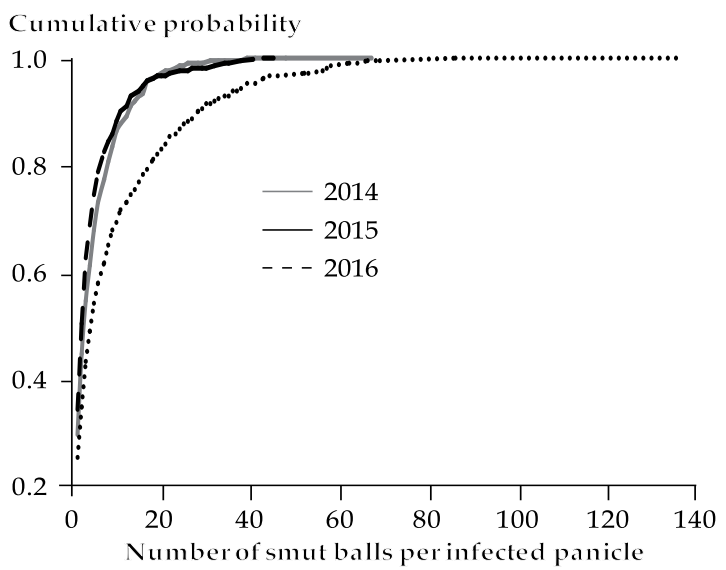

Fig. 2. Cumulative probability of occurring number of false smut balls on infected rice panicles in three $\mathrm{T}$. Aman seasons - 2014, 2015 and 2016.

Results show the evidence of yearly variability in smut ball formation on infected rice panicles (Fig. 2). Comparatively more balls formed in 2015 than 2014 or 2016 seasons. Between 2014 and 2016, the difference was small. Analyses show that among weather variables, yearly difference in daily minimum temperatures reflected on the density of smut ball formation (Fig. 3). During midSeptember to mid-November, when the disease prevailed on T. Aman rice, the average daily minimum temperature was lower $\left(20.8 \pm 3.0^{\circ} \mathrm{C}\right.$, \pm is standard deviation) in 2015 than 2014 $\left(22.6 \pm 2.7^{\circ} \mathrm{C}, \pm\right.$ is standard deviation) or 2016 $\left(24.4 \pm 2.1^{\circ} \mathrm{C}, \pm\right.$ is standard deviation).

Density and Distribution of False Smut Balls 75 


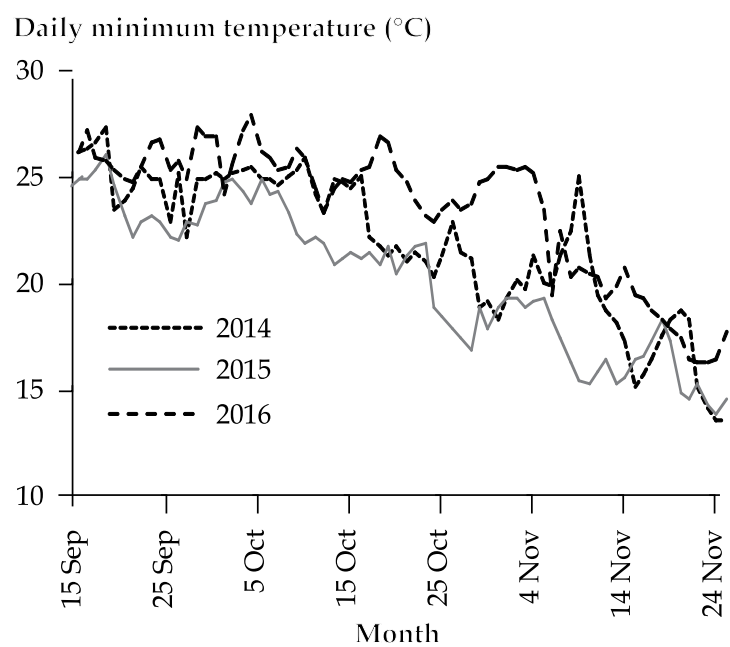

Fig. 3. Daily minimum air temperatures in the study area BRRI research, Gazipur, Bangladesh) in three T. Aman seasons - 2014, 2015 and 2016.

Yield loss (\%)

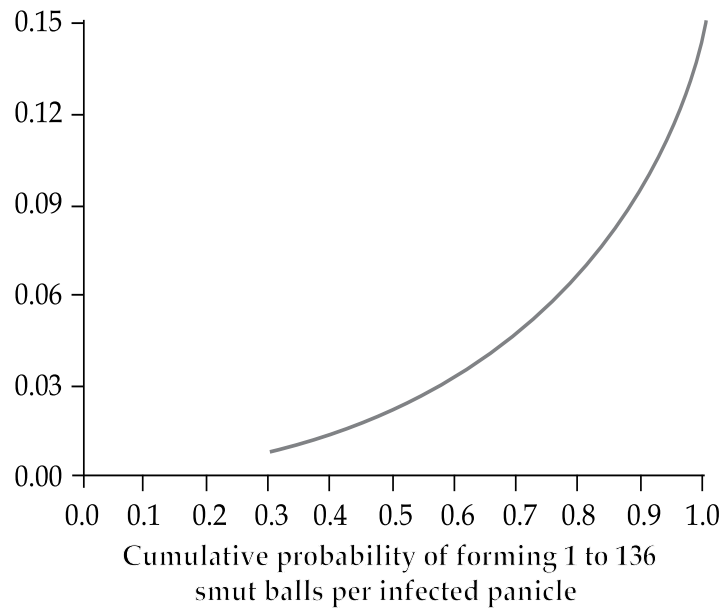

Fig. 4. Estimated yield loss (\%) per 1\% incidence in rice false smut disease resulting from incremental number of smut balls per infected panicle from 1 to 136 observed in the study area during 2014, 2015 and 2016.

Estimated yield loss from density of false smut balls on infected rice panicles

With cumulative probability of increment of smut balls per infected panicle from 1 to 136 observed in three years (2014-2016), the yield loss was estimated as $0.15 \%$ for $1 \%$ of disease incidence (Fig. 4).

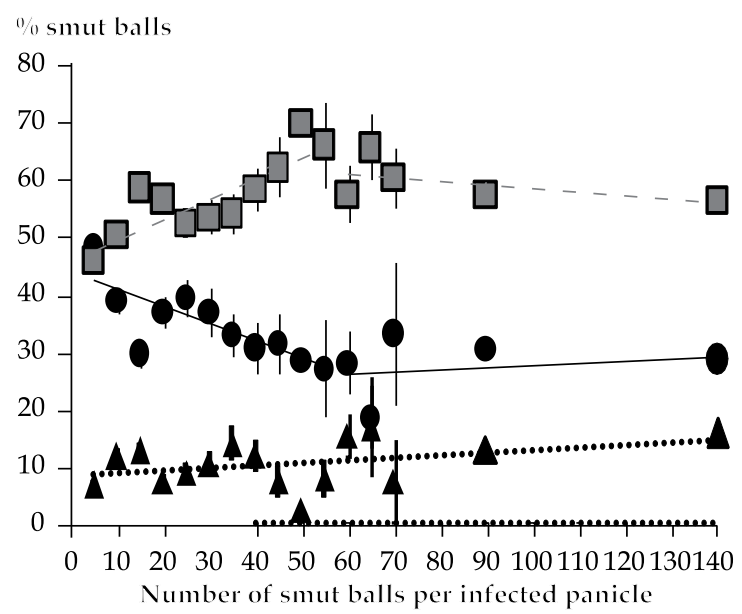

Fig. 5. Density (expressed as percentage) of false smut balls in three positions $($ base $=$ filled circle, $\mathrm{mid}=$ filled squares, and apex $=$ filed triangles) of infected rice panicles shown in relation to number of smut balls per infected panicle. Vertical bars are confidence interval at $95 \%$ probability level. Horizontal lines are linear regression lines explained in the text.

\section{Distribution of false smut balls on naturally and simulated infected panicles}

When the number was low (5 or below), $48.1 \pm 3.5 \%$ ( \pm is $95 \%$ confidence interval) false smut balls was located at the base, $45.5 \pm 3.4 \%$ ( \pm is $95 \%$ confidence interval) at the mid and only $6.4 \pm 1.7 \%$ ( \pm is $95 \%$ confidence interval) at the apex section of the infected rice panicles (Fig. 5). As the number increased (up to 55), the false smut ball formation gradually increased at the mid and decreased at the base of the infected panicles. This change is explained in the regression equations: $Y=43.129-0.2943 X\left(R^{2}\right.$ $=0.61 ; n=11)$ for base, and $Y=46.072+0.3545$ $\mathrm{X}\left(R^{2}=0.71 ; n=11\right)$ for mid section of infected panicle. When the ball number increased above 55 , this change was almost static for both base $\left(24.039+0.379 \mathrm{X} ; R^{2}=0.05 ; n=5\right)$ and $\operatorname{mid}(\mathrm{Y}$ $\left.=70.306-0.2042 \mathrm{X} ; R^{2}=0.19 ; n=5\right)$ sections of the infected panicles. The number of false smut balls identified in the apex part of the infected panicles was low ( $15 \%$ at the maximum), whose proportion increased slowly but insignificantly with the increase in the number of smut balls per infected panicles $\left(\mathrm{Y}=8.3077+0.0437 \mathrm{X} ; R^{2}\right.$ $=0.14 ; n=15)$. When the healthy panicles were 
investigated, the number of filled grains was significantly higher in mid $(40.4 \pm 5.1 \%, \pm$ is $95 \%$ CI) compared to base $(21.5 \pm 3.0 \%, \pm$ is $95 \% \mathrm{CI})$ or apex $(22.5 \pm 2.4 \%, \pm$ is $95 \% \mathrm{CI})$ (Fig. 6). On the other hand, the number of unfilled grains was recorded low and statistically similar (4.1 to $5.8 \%)$ in the three sections.

When compared false smut balls in the three portions (base, mid and apex) of infected

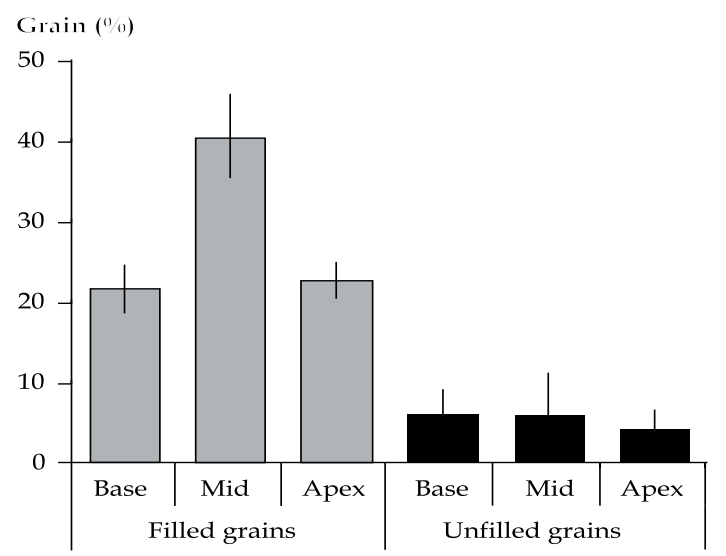

Fig. 6. Proportion of filled and unfilled grains in three portions (base, mid and apex) of healthy panicles.

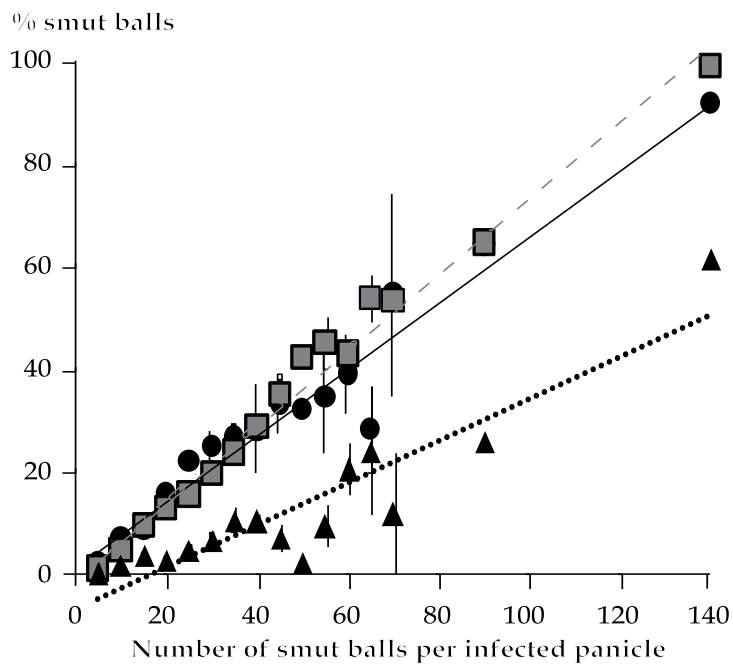

Fig. 7. Proportion of false smut balls in three positions (base $=$ filled circle, mid $=$ filled squares, and apex $=$ filed triangles) of infected rice panicles in relation to potential grain number. Vertical bars are confidence interval at $95 \%$ probability level. Horizontal lines are linear regression lines explained in the text. panicles in relation to potential grain number (shown in Fig. 6), the proportion accounted for the base $\left(Y=1.82+0.64 X ; R^{2}=0.95 ; n=\right.$ $15)$ and $\mathrm{mid}\left(\mathrm{Y}=-0.48+0.74 \mathrm{X} ; R^{2}=0.99 ; n\right.$ $=15$ ) remained almost similar (Fig. 7). This proportion in the apex portion of the infected panicles was much lower than base or midsection of the panicles $\left(\mathrm{Y}=-6.42+0.41 \mathrm{X} ; R^{2}=\right.$ $0.84 ; n=15)$.

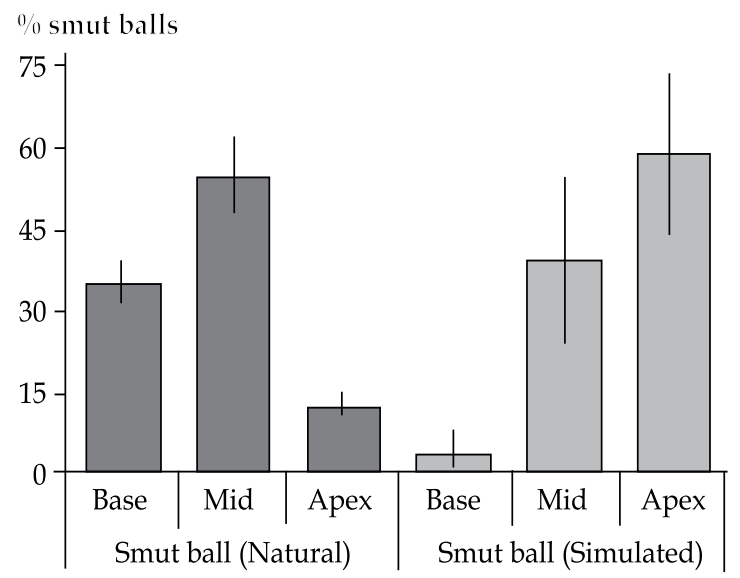

Fig. 8. Comparison of smut balls in three positions of naturally and simulated infected panicles.

Smut balls per infected panicle under natural infection

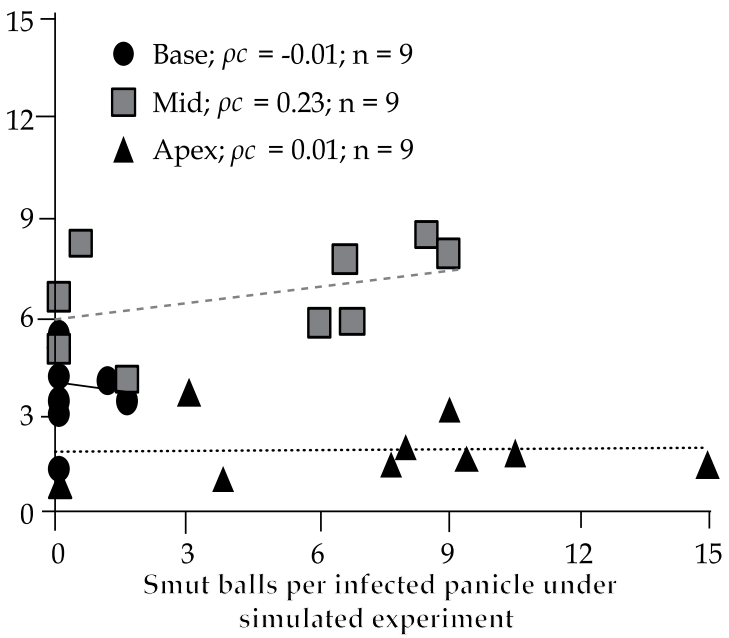

Fig. 9. Relationship of smut balls on naturally and simulated infected panicles in three positions (base $=$ filled circle, mid $=$ filled squares, and apex $=$ filed triangles) across nine panicle lengths (16 to $24 \mathrm{~cm}$, interval 1). The $\rho c$ denotes the concordance correlation coefficient.

Density and Distribution of False Smut Balls 77 
In the natural observation, on average, $34.4 \pm 4.3,53.9 \pm 7.3$ and $11.7 \pm 2.3 \%( \pm$ is $95 \%$ confidence interval) of the smut balls were located at the base, mid and apex of the infected panicles, respectively. On the contrary, the pattern was $3.1 \pm 4.3,38.7 \pm 15.5$ and $58.2 \pm 15.1 \%$ ( \pm is $95 \%$ confidence interval) in simulated observation (Fig. 8).

The relationship of the smut balls across nine panicle lengths on naturally and simulated infected panicles was insignificant (Fig. 9).

\section{DISCUSSION}

The present study, density and distribution of false smut balls on infected rice panicles, has two major implications on understanding, (i) yield loss from the rice false smut (RFSm) disease, and (ii) natural route of entry of the pathogen into the host. A study similar to this, to best of our knowledge, has not been widely reported.

The yield loss by the disease in a rice population is panicle-specific (inflorescence), i.e. it depends on how severely the panicles are infected. This severity can be expressed by the number of smut balls present on infected panicles. While this number can reach as high as 136 (as recoded in 2015) on infected panicles, our three year's study shows there is $81 \%$ probability that nine or less smuts balls will form, $54 \%$ probability that three or less smut balls will form and 30\% probability that only one smut ball will form. We used data from early investigation in Japan (Ikegami, 1962) and calculated $85 \%$ probability that three or less smut balls will form and 54\% probability that only one smut ball will form. This indicates the reported severity of RFSm in Japan was less than the results from this study. The seasonal variation affected the level of false smut ball density on infected rice panicles, higher severity was probably influenced by low daily minimum temperature as in the case of 2015 scenario; Ikegami's (1962) findings also reflected such variation. Tanaka et al. (2017) revealed that occurrence of the RFSm negatively influenced by higher temperatures during booting stage of the crop. The scenario of the density of false smut balls on infected rice panicles quantified in the three-year investigation provided a general perception of yield loss had been occurring in the studied riceecosystem. Using the FLYER model developed recently (Nessa et al., 2015a) with inputs from the present study, we estimated the yield loss of $0.15 \%$ per $1 \%$ incidence level. The incidence level is the percentage of diseased panicles in the ecosystem. In the study area the average incidence hardly exceeding $2.5 \%$ (Nessa et al., 2015c), which suggests that the aggregated yield loss would be very small $(\sim 0.37 \%)$.

The epidemiology of RFSm with respect to inoculum source(s), dispersion and point of entry of the pathogen into plant and overall infection process is still on debate (discussed in Nessa et al., 2015b). A series of recent papers being successful in causing artificial inoculation at booting stage before heading (e.g. Ashizawa et al., 2012) led to the opinion that spores (ascospores or chlamydospores) enter into the booting sheath along with water flowing on the top leaves. Guo et al. (2012) view the hypothesis that water flowing brings the primary infection source into the sheath is consistent with the observation that the disease is much more severe when rice heading stage is located in rainy and high humidity days. Our simulation experiment mimicked that fungal spores drip as water drops through the junction of flag leaf and ligule in the late boot stage. If this had happened naturally in the field, it was more likely that grains in the apex portion of the infected panicles would have been largely infected, as revealed in the simulation results. On the contrary, we recorded, under natural infection, absolute predominance of distribution of false smut balls on the base and mid portions of the infected panicles. A similar pattern of smut ball distribution was reported by Ikagami (1962). Our findings, supported by Ikegami (1962), indicate that the false smut pathogen might not enter into panicles from air with water droplet through the junction of flag leaf and ligule. The recent findings from Japan suggest that the rice false smut fungus $V$. virens colonizes rice root tissues and the surface of tiller buds enveloped by juvenile leaf sheaths until the booting stage (Tanaka et al., 2017). 
CONCLUSION

High probability $(81 \%)$ of low density (maximum of 9) of false smut balls was observed in the studied rice-ecosystem. Our research clearly shows that the pathogen has an affinity of producing symptoms (false smut balls) on the lower half of the infected rice panicles. It is not yet explainable why such affinity exists with the pathogen. Furthermore, such distribution pattern of smut balls on the infected panicles may be an indication of entry of the pathogen into the plant from below the base of the panicle; thereafter it spreads upwardly. Future research should be directed to address these issues.

\section{ACKNOWLEDGEMENTS}

This study is a part of $\mathrm{BN}^{\prime}$ 's on-going $\mathrm{PhD}$ research. The Bangladesh Agricultural Research Council (BARC) offered a PhD fellowship, and the Bangladesh Rice Research Institute (BRRI) granted study leave and provided with research facilities to run the $\mathrm{PhD}$ programme $\mathrm{BN}$ deeply acknowledges both BARC and BRRI for that. MUS thanks the Department of Agriculture and Food Western Australia (DAFWA) for facilitating a semi-sabbatical arrangement to be involved in the study, and BRRI for hosting him. BN is grateful to the BRRI Plant Pathology Division for providing facilities to conduct the experiments. JG acknowledges DAFWA for providing opportunity to contribute to this project.

\section{REFERENCE}

Ashizawa, T, M Takahashi, J Moriwaki and K Hirayae. 2010. Quantification of the rice false smut pathogen Ustilaginoidea virens from soil in Japan using realtime PCR. Eur. J. Plant Pathol. 128: 221-232.

Ashizawa, T, M Takahashi, M Arai and T Arie. 2012. Rice false smut pathogen, Ustilaginoidea virens, invades through small gap at the apex of a rice spikelet before heading. J. Gen. Plant Pathol. 78: 255-259.

Atia, M M M. 2004. Rice false smut (Ustilaginoidea virens) in Egypt. J. Plant Dis. Protection. 111: 71-82.

Brooks, S A, M M Anders and K M Yeater. 2009. Effect of cultural management practices on the severity of false smut and kernel smut of rice. Plant Dis. 93: 1202-1208.
Fan, J, X-Y Guo, L Li, F Huang, W-X Sun, Y Li, Y-Y Huang, Y-J Xu, J Shi, Y Lei, A-P Zheng and W-M Wang. 2015. Infection of Ustilaginoidea virens intercepts rice seed formation but activates grain-filling-related genes. J. Integr. Plant Biol. 57: 577-590.

Guo, X, Y Li, J Fan, L Li, F Huang and W Wang. 2012. Progress in the study of false smut disease in rice. J. Agric. Sci. Tech. A2: 1211-1217.

Ikegami, H. 1962. Studies on the false smut of rice V. Seedling inoculation with the chlamydospores of the false smut fungus. Res. Bull. Faculty Agriculture Gifu Univ. XXVII: 16-23.

Kabir, M S , M U Salam, A Chowdhury, N M F Rahman, K M Iftekharuddaula, M S Rahman, M H Rashid, S S Dipti, A Islam, M A Latif, A K M S Islam, M M Hossain, B Nessa, T H Ansari, M A Ali and J K Biswas. 2015. Rice Vision for Bangladesh: 2050 and Beyond. Bangladesh Rice J. 19: 1-18.

Li, W, L Li, A Feng, X Zhu and J Li. 2013. Rice false smut fungus, Ustilaginoidea virens, inhibits pollen germination and degrades the integuments of rice ovule. Am. J. Plant Sci. 4: 2295-2304.

Lin, L I-K. 1989. A concordance correlation coefficient to evaluate reproducibility. Biometrics. 45: 255-268.

Nessa, B, M U Salam, A H M M Haque, J K Biswas, W J MacLeod, M A Ali, K P Halder and J Galloway. 2015a. FLYER: A simple yet robust model for estimating yield loss from rice false smut disease (Ustilaginoidea virens). Am. J. Agric. Biol. Sci. 10: 41-54.

Nessa, B, M U Salam, A H M M Haque, J K Biswas, M S Kabir, W J MacLeod, M D'Antuono, H N Barman, M A Latif and J Galloway. 2015b. Spatial pattern of natural spread of rice false smut (Ustilaginoidea virens) disease in fields. Am. J. Agric. Biol. Sci. 10: 63-73.

Nessa, B, M U Salam, A H M M Haque, J K Biswas, M A Latif, A Ali, T H Ansari, M Ahmed, N Parvin, M Z I Baki, S Islam, M S Islam and J Galloway. 2015c. Rice false smut disease at different flowering times. Bangladesh Rice J. 19: 29-35.

Ou, S H. 1972. Rice Diseases. Kew: Commonwealth Mycological Institute, UK. P. 380.

Singh, S, A A Lal, S Simon, A Singh, R Taduman, Kamaluddeen, A A David. 2014. Survey of false smut (Ustilaginoidea virens) of rice (Oryza sativa L.) in selected districts of Utter Pradesh, India. The Bioscan. 9: 389-392.

Tanaka, E, T Kumagawa, N Ito, A Nakanishi, Y Ohta, E Suzuki, N Adachi, A Hamada, T Ashizawa, T Ohara and M Tsuda. 2017. Colonization of the vegetative stage of rice plants by the false smut fungus Villosiclava virens, as revealed by a combination of species-specific detection methods. Plant Pathol. 66: 56-66.

Upadhyay, A L and R V Singh. 2013. Yield loss assessment in rice due to false smut. Annals of Plant and Soil Res. 15: 173-174.

Willmott, C J, S G Ackleson, R E Davis, J J Feddema, K M Klink, D R Legates, J O'Donnell and CM Rowe. 1985. Statistics for the evaluation and comparison of models. Geophysical Res. 90: 8995-9005.

Density and Distribution of False Smut Balls 
